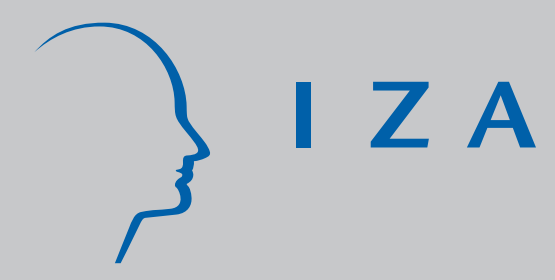

IZA DP No. 1070

Are Wage and Employment Effects Robust to Alternative Minimum Wage Variables?

Sara Lemos

March 2004 


\title{
Are Wage and Employment Effects Robust to Alternative Minimum Wage Variables?
}

\author{
Sara Lemos \\ University of Leicester \\ and IZA Bonn
}
Discussion Paper No. 1070
March 2004

\author{
IZA \\ P.O. Box 7240 \\ 53072 Bonn \\ Germany \\ Phone: +49-228-3894-0 \\ Fax: +49-228-3894-180 \\ Email: iza@iza.org
}

\begin{abstract}
Any opinions expressed here are those of the author(s) and not those of the institute. Research disseminated by IZA may include views on policy, but the institute itself takes no institutional policy positions.

The Institute for the Study of Labor (IZA) in Bonn is a local and virtual international research center and a place of communication between science, politics and business. IZA is an independent nonprofit company supported by Deutsche Post World Net. The center is associated with the University of Bonn and offers a stimulating research environment through its research networks, research support, and visitors and doctoral programs. IZA engages in (i) original and internationally competitive research in all fields of labor economics, (ii) development of policy concepts, and (iii) dissemination of research results and concepts to the interested public.
\end{abstract}

IZA Discussion Papers often represent preliminary work and are circulated to encourage discussion. Citation of such a paper should account for its provisional character. A revised version may be available on the IZA website (www.iza.org) or directly from the author. 


\title{
ABSTRACT \\ Are Wage and Employment Effects Robust to Alternative Minimum Wage Variables?
}

\begin{abstract}
A national minimum wage cannot explain variation in wages or employment across regions. Identification of the effect of the minimum wage separately from the effect of other variables on wages or employment requires regional variation. Many minimum wage variables with regional variation have been suggested in the literature. Such a variety of variables makes it difficult to compare estimates across studies. First, estimates using different minimum wage variables are not always calibrated to represent the effect of a $10 \%$ increase in the minimum wage on wages or employment. Second, different minimum wage variables might simply measure the effect of the minimum wage on different workers. Part of the controversial recent debate in the literature over the magnitude and direction of the employment effect might be that non-directly comparable estimates are being compared. This paper estimates and critically compares the effects of the minimum wage on both wages and employment using five minimum wage variables common in the literature: real minimum wage, "Kaitz index", "fraction affected", "fraction at" and "fraction below" the minimum wage. The data used is a Brazilian monthly household survey from 1982 to 2000. The estimates are robust and indicate that an increase in the minimum wage compresses the wages distribution with small adverse effects on employment.
\end{abstract}

JEL Classification: J38

Keywords: minimum wage, wage effect, employment effect, Brazil

\author{
Sara Lemos \\ Economics Department \\ University of Leicester \\ University Road \\ Leicester LE1 7RH \\ United Kingdom \\ Tel.: +44116252 2480 \\ Fax: +44116252 2908 \\ Email: sl129@leicester.ac.uk
}




\section{Introduction}

A national minimum wage cannot explain variation in wages or employment across regions. Identification of the effect of the minimum wage separately from the effect of other variables on wages or employment requires regional variation. Many minimum wage variables with regional variation have been suggested in the literature. Such a variety of variables makes it difficult to compare estimates across studies. First, estimates using different minimum wage variables are not always calibrated to represent the effect of a $10 \%$ increase in the minimum wage on wages or employment. Second, different minimum wage variables might simply measure the effect of the minimum wage on different workers. Part of the controversial recent debate in the literature over the magnitude and direction of the employment effect might be that non-directly comparable estimates are being compared.

This paper estimates and critically compares the effects of the minimum wage on both wages and employment using five minimum wage variables common in the literature: real minimum wage, "Kaitz index", "fraction affected", "fraction at" and "fraction below" the minimum wage. The data used is a Brazilian monthly household survey from 1982 to 2000.

The minimum wage is expected to have a direct impact on the wage of those between the old and the new minimum wage and an indirect impact on the wage of those above (and below) the new minimum wage. The indirect spillover effects result from wage comparisons, inflationary expectations and labour substitution following a minimum wage increase (Gramlich, 1976; Sellekaerts, 1981; Grossman, 1983). Thus, the effect of a binding minimum wage on other wages is expected to be positive. Its magnitude is expected to vary across the wages distribution because different occupations have different comparison groups (Sellekaerts, 1981; Grossman, 1983; Akerlof, 1982 and 1984). Elasticities are expected to be larger at lower percentiles, resulting on a compression effect (Brown, 1999; Card and Krueger, 1995).

Once the compression effect is observed, the policy debate hinges on the minimum wage employment effect. The 80 s consensus of a negative significant but modest $-1 \%$ to $-3 \%$ employment effect (Brown, et al., 1982) has been challenged. On the one hand, Neumark and Wascher (1992 and 2000), Deere et al. (1995 and 1996), Currie and Fallick (1996) and Burkhauser et al. (2000), among others, found results consistent with the standard model prediction of a negative employment effect. On the other hand, Card and Krueger (1995 and 2000), Machin et al. (2003), Machin and Manning (1994), and Dickens et al. (1999), among others, were unable to find disemployment effects. Explanations to non-negative effects range from theory to empirical identification and data issues (Card and Krueger, 1995; Brown, 1999). While there is yet no consensus, small employment effects, clustered around zero, are becoming prevalent in the literature (Freeman, 1994 and 1996; Brown, 1999).

The evidence for Brazil, in line with the international evidence, suggests that minimum wage increases compress the wage distribution but does not always have a significant effect on employment 
and it is not always negative (up to -1\%) (Neri, 1997; Fajnzylber, 2001; Carneiro, 2002; Corseuil and Servo, 2002; McIntyre, 2002; Neumark et al., 2003).

Further to providing a benchmark in the literature by comparing alternative minimum wage variables estimates, this paper also discusses a number of conceptual and identification questions. For example:

First, an employment decomposition is formalized to separately estimate the effect of the minimum wage on the number of hours worked and on the number of jobs. This decomposition has not been previously formalized in the literature.

Second, this paper follows recent strands in the international literature - not previously appearing in the Brazilian literature - to estimate wage distributional effects. Individual micro data is used to estimate before-and-after non-parametric Kernel wage distributions that are a visually appealing illustration of the minimum wage compression effect. This is then formalized by estimating the effect of the minimum wage at various percentiles across the distribution controlling for the effect of other variables on wages.

Third, this paper uses under-explored Brazilian data to estimate minimum wage effects. Most of the existing literature is available for the US; further empirical evidence is urged for both other developed and developing countries (Hamermesh, 2002). Using non-US data is an unbiased way of extending the understanding of minimum wage effects and assessing the robustness of findings for the US. Although results for Brazil might not be directly informative about the robustness of results for the US because of differences in the structure of labour market and the economy more generally, this paper represents an important contribution not only to the academic literature but also to policymaking - specially given South America Governments recent promises of minimum wage increases (The Economist, 2002a, 2002b and 2003.

This paper is organized as follows. Section 2 presents the data; it describes the minimum wage in Brazil (Section 2.1), presents descriptive statistics (Section 2.2) and defines minimum wage variables (Section 2.3). Section 3 presents wage models (Section 3.1), followed by a discussion on identification (Section 3.2), model re-specification (Section 3.3) and robustness checks (Section 3.4). Section 4 presents employment models (Section 4.1), formalizes the employment decomposition (Section 4.2), presents a model re-specification (Section 4.3) and robustness checks (Section 4.4). Section 4.5 discusses why the employment effects are small and Section 5 concludes. The estimates are robust and indicate that an increase in the minimum wage compresses the wages distribution with small adverse effects on employment. 


\section{Data and Descriptive Analysis}

\subsection{Minimum Wage}

The nominal minimum wage in Brazil is national and coverage is full. ${ }^{1}$ The real minimum wage has decreased over time because of its effect on both the public deficit and inflation. First, the fiscal impact has often been a constraint for more generous minimum wage increases (Foguel et al., 2001). Second, after the dictatorship in 1964 associated high inflation with wage adjustments, the minimum wage started to play the roles of indexor and numeraire in the economy. The nominal minimum wage was used as deflationary policy, via under-indexation of the real minimum wage, and as coordinator of the wage policy (Carneiro and Faria 1998). This transformed it from a social policy against inequality and poverty into a stabilization policy against inflation (Camargo, 1984, p.19). Subsequent increases in inequality were later associated with the pos-64 real minimum wage decrease (Souza and Baltar, 1979, 1980; Macedo and Garcia, 1978 and 1980).

The nominal and real hourly minimum wage in the sample period is shown in Graphs 1.a and 1.b. ${ }^{2}$ Several plans to stabilize inflation had different nominal minimum wage indexation rules. In early 1986 , adjustments were bi-annual adjustments; in mid-1987, after the minimum wage wages were frozen for 3 months, they were monthly indexed by past inflation. In early 1989, wages and prices were again frozen and from mid-1989 adjustments were again monthly. In early 1990 no indexation rules were in place. In late 1991, indexation was restricted to workers earning up to 3 time the minimum wage. In 1993 adjustments were bi-monthly and then monthly. In early 1994 a daily indexer was introduced. Since mid-1995 adjustments have been annually. The result of these indexation rules is the saw-toothed pattern in Graph 1.b, particularly remarkable within years of high inflation.

\subsection{Wages and Employment}

The data used is PME (Monthly Employment Survey) from 1982 to 2000 - a rotating panel data (for the six main Brazilian metropolitan regions) with a similar design to the US CPS. The deflator is the INPC (National Consumers Price Index) disaggregated by regions. All data is available from IBGE (Instituto Brasileiro de Geografia e Estatistica).

\footnotetext{
${ }^{1}$ The minimum wage was regional from its introduction in 1940 until 1984. Accommodation and food costs can be deducted from the wage. That might account for some below minimum wage workers, although the majority of those are informal sector workers.

${ }^{2}$ The hourly minimum wage is the monthly minimum wage devided by $44 \times 4.3$ after, and $48 \times 4.3$ until September of 1988 , because the new Constitution shortened the working week. Similarly, the hourly wage rate is monthly earnings devided by the weekly hours worked multiplied by 4.3 .
} 
Table 1 summarizes the main aspects of the data. It shows population, labour market, and economic descriptive statistics for the full sample, Pernambuco (PE) (a poor region), and Sao Paulo (SP) (a rich region), on a low (Dec-1984) and a high (Dec-1992) inflation year. PE has a smaller proportion of workers, and a higher proportion of children, retirees, students, and workers enrolled in schooling. Workers in PE are younger, less educated, work more in the informal and public sectors and in rural areas; are paid lower wages, suffer more from inequality and unemployment, and work longer hours.

Panel III of Table 1 shows selected percentiles, the mean and the standard deviation of the log hourly real wage distribution. For all percentiles, PE (SP) showed lower (higher) wages than the national aggregate in 1984. However, in 1992 this is only true in the bottom half of the distribution; in the top of the distribution, wages are higher in the national aggregate. This suggests that the low paid are better off in SP than in PE. Correlations of both log hourly real wage distribution $25^{\text {th }}$ and $75^{\text {th }}$ percentiles against the $\log$ hourly real minimum wage are 0.78 and 0.73 , suggesting that the minimum wage is more correlated with lower percentiles. ${ }^{3}$ Such correlations for PE and SP are respectively 0.95 and 0.36 , and 0.78 and 0.55 .

Panels II and III of Table 1 show that the employment rate went down and the informal sector became larger in both regions. Worsening macroeconomic conditions not only replaced formal with informal sector jobs, but also destroyed jobs. Although a smaller proportion of people are in employment, they work longer hours on average in PE than in SP (although these numbers are converging). Correlations of both log average hours worked by those working and log employment rate against log real hourly minimum wage are 0.26 and 0.15 (-0.07 and 0.12$)$ in levels (differences). The positive correlation in levels fades as the data is differenced but offers little support for a negative effect of the minimum wage on employment. Such correlations for PE and SP in levels are respectively 0.42 and 0.28 , and 0.37 and 0.01 .

\subsection{Minimum Wage Variables}

Graph 1.c shows log "Kaitz index", defined as the ratio of the minimum wage to average wage adjusted for coverage (Kaitz, 1970), whose correlation with the log real minimum wage is 0.81 . While the "Kaitz index" was 0.39 and 0.40 for the US and UK in 1993 (Dolado et al., 1996), it was 0.27 for Brazil and 0.45 for PE. A better minimum wage variable if wage inequality is substantial as in Brazil (Bacha, 1979; Fernandes and Menezes-Filho, 2000) might be the ratio of the minimum wage to the median wage, log "Kaitz index 50", whose correlations with the log real minimum wage is also 0.81 .

\footnotetext{
${ }^{3}$ Correlations reported in Sections 2.2 and 2.3 are in the national aggregate unless otherwise noted.
} 
Graph 1.d shows "fraction affected" (Card, 1992), defined as the fraction of workers earning wages in the interval $0.98 * m w_{t-1} \leq w a g e_{t-1} \leq 1.02 * m w_{t}$ (0.98 and 1.02 account for rounding approximations), whose correlation with the log real minimum wage is 0.57 . "Fraction affected" is zero whenever the minimum wage was not increased; when nonzero, its magnitude is associated to the size of the increase. While "fraction affected" was 7.4\% for the US in 1990 (Card and Krueger, 1995), it was 8\% for Brazil and $49 \%$ for PE.

Graph 1.e shows "fraction at" (Dolado et al., 1996), defined as the fraction of workers earning wages in the interval $0.98 * m w_{t} \leq w a g e_{t} \leq 1.02 * m w_{t}$, whose correlation with the log real minimum wage is 0.64. "Fraction at" responds to minimum wage increases; it is bigger after an increase and smaller as workers wage bargain (Card and Krueger, 1995). This is accentuated if inflation is high and the minimum wage is constant (Carmargo, 1984). While the "fraction at" was 4\% for the US in 1993 (Dolado et al., 1996), it was $12 \%$ for Brazil and $25 \%$ for PE. ${ }^{4}$

Graph 1.f shows "fraction below" the minimum wage (Dolado et al., 1996), defined as the fraction of workers earning wages in the interval wage $_{t} \leq 1.02 * m w_{t}$, whose correlation with log real minimum wage is 0.71 . This suggests that larger minimum wage increases trap more workers below the minimum wage, and therefore "fraction below" also moves in response to minimum wage increases.

All the above variables are measures of the bite of the minimum wage. "Kaitz index" and "Kaitz index 50", together with the real minimum wage, are "relative minimum wage measures". The other variables are called "degree of impact measures" (Brown, 1999) because they focus on the fraction of workers directly affected by minimum wage increases. They measure the effect of increases on different workers: "fraction affected" is a measure of the potential effect of the increase, "fraction at", of the effectiveness of the increase, and "fraction below", of the non-compliance with the increase.

\subsubsection{Source of Variation in the Minimum Wage Variables}

"Relative minimum wage measures" are commonly used in empirical employment models because they are grounded on the standard neoclassical model (Card and Krueger, 1995; Williams, 1993). The implicit assumption is that the minimum wage varies across regions. If however the numerator is constant, the variation in the ratio is entirely driven by the variation in the denominator (average wage,

\footnotetext{
4 "Fraction at" is defined here using real monthly earnings as opposed to real hourly wages used in Graph 1.e and in estimations in Sections 3 and 4. The first is bigger at every point in time because workers who earn the monthly minimum wage but work shorter (longer) hours than the typical workweek will earn above (below) the hourly minimum wage. Whatever measurement error thus introduced was random enough to produce estimates robust to either definition. Hourly definitions ensure that the results are consistent with theory and comparable with the existing empirical literature. It also plays an important role in the employment decomposition in Section 4.2.
} 
median wage or price level) (Welch and Cunningham, 1978; Freeman, 1982). As a result, the variation in such variables is not a measure of the variation in the minimum wage.

Although a national minimum wage is a difficulty when defining "relative minimum wage measures" empirically, it is what makes it possible to define "degree of impact measures". Because the minimum wage affects a different proportion of people in each region, it is a measure of the bite of the minimum wage across regions. That is what theory suggests, a measure of the bite (Dickens at al., 1999; Williams, 1993). Comparisons between "degree of impact measures" and the "relative minimum wage measures" led some to conclude that the former are conceptually cleaner (Brown, 1999). That is because they measure the mass of the distribution at the point that really matters (Neri, 1997). Analyses based on other moments, for example the mean ("Kaitz index"), include workers not affected by the minimum wage (Castillo-Freeman and Freeman, 1992).

Even though the ultimate source of variation in both the "degree of impact measures" and the "relative minimum wage measures" is the wage level in each region, an increase in the national minimum wage causes direct and immediate variation on the former, whereas it causes only indirect and lagged variation (via average wages, median wages or price level) on the later. This indirect and lagged variation might be contaminated by variation in variables other than the minimum wage. Furthermore, the shape of the distribution, especially if inequality is substantial, causes more variation in the "degree of impact measures".

Among the "degree of impact measures" the amount of variation differs. Brown (1999, p. 2130) notes: "fraction affected" is "not well-suited for studying periods when the minimum wage is constant, and so its impact should be declining. While there is more to be learned from a year in which the minimum wage increases by 10 or $15 \%$ more than average wages than from a year of modest decline, the periods between increases should together contain about as much information as the periods of increase." That is because "fraction affected" is zero regardless of how unimportant the minimum wage might become. As a result, it does not capture the erosion of the minimum wage relative to other wages (Neumark and Wascher, 1994).

"Fraction at" does not suffer from the same drawback, as it can be defined even when the minimum wage is constant. "Fraction at" is a better measure of the importance of the minimum wage because it measures both how binding the minimum wage is when increased, and how unimportant (not binding) when not increased. "Fraction at" has a stronger correlation with the real minimum wage (0.64) than "fraction affected" (0.57); it has more variation across regions and over time (Graphs 1.d and 1.e). Beyond statistical variation, "fraction at" is a measure of those workers becoming more expensive, i.e. a measure of extra (wage) employment costs, and therefore well suited to study wage and employment effects. 
To establish whether the variation in "fraction at" is a measure of the variation in the minimum wage, consider three scenarios. First, if the increase is fully anticipated, allowing wage bargains which result in $100 \%$ spillover (all workers keep their position in the wage distribution), "fraction at" is constant regardless of the size of the increase and therefore uncorrelated with it. Second, if the increase is fully anticipated, but wage bargains result in less than $100 \%$ spillover, "fraction at" is correlated to the increase. The less spillover (i.e., the less "leakage" of workers out of the minimum wage into higher or lower wage positions), the higher the correlation. Third, if the increase is not anticipated, no wage bargains occur resulting in $0 \%$ spillover; all workers between the old and new minimum wage are squashed at the later. "Fraction at" is then correlated to the increase, and this correlation is clear of "leakages". Therefore, the underlying identifying restrictions for a valid control group are that a fully anticipated increase is not followed by $100 \%$ spillover - these are fairly realistic assumptions.

The variation in "fraction below" is qualitatively similar to the variation in "fraction at". However, "fraction at" measures variation directly caused by minimum wage increases and is therefore a cleaner measure of the minimum wage effect. Variation in "fraction below" depends not only on how binding the minimum wage is but also on the extent of non-compliance, which might be affected by variables other than the minimum wage. Nonetheless, "fraction below" has a stronger correlation with the real minimum wage (0.71) than "fraction at" $(0.64)$.

\section{Wages Effects}

\subsection{Model Specification}

Graph 2 shows the wage distribution for each month of 1992 before and after the minimum wage increase. Graphs titled April-May, August-September and December-January show the change in the shape of the distribution after minimum wage increases (the right-most distribution), confirming the expected compression effect. If, in the absence of a minimum wage increase, the wage distribution was stable over time, then this simple comparison of distributions would be an estimate of the minimum wage effect (Meyer and Wise, 1983). However, shifts in the distribution might be due to changes in variables other than the minimum wage. Regression models control for such variables.

Consider the following empirical model, grounded on the standard neoclassical theoretical model, where wage is a function of the minimum wage:

$$
\Delta \log \text { rwage }_{r t}=\alpha^{w}+\beta^{w} \Delta \log r M W_{r t}+\gamma^{w} \text { inf } \text { lation }_{r t-1}+\delta^{w} \text { urate }_{r t}+\lambda^{w} \text { controls }_{r t}+f_{r}^{w}+f_{t}^{w}+u_{r t}^{w}
$$

where rwage $_{r t}$ is average real wages in region $r$ in time $t, r=1, \ldots, 6$, and $t=1, \ldots, 214 ; r M W_{r t}$ is real minimum wage; inf lation $_{r t-1}$ is past inflation; urate $_{r t}$ is unemployment rate; controls $_{r t}$ are supply shifters; $f_{r}^{w}$ and $f_{t}^{w}$ are region and time fixed effects (modelled by region and time dummies) (Section 
3.2); and $u_{i r t}^{w}$ is the error term. This model can be estimated not only using average wages but also the $10^{\text {th }}, 20^{\text {th }}, 30^{\text {th }}, 40^{\text {th }}, 50^{\text {th }}$ and $90^{\text {th }}$ wage distribution percentiles. That way, the minimum wage effect at various points across the distribution is estimated (Dickens et al., 1999).

As Equation (1) is a reduced form, it includes supply shifters. Here, these are mainly population and institutional variables that control for region specific demographics correlated with the minimum wage, i.e. the proportion of people in the population who are: young, younger than 10 years old, women, illiterates, retirees, students, in the informal sector, in urban areas, in the public sector, in the building construction industry sector, in the metallurgic industry sector, basic education and high school degree holders, and the proportion of workers with a second job (see Table 1). ${ }^{5}$

The model was estimated in first-differences because the conceptual question of interest is how changes in the minimum wage, change wages (Card and Krueger, 1995; Dickens et al. 1999). Dummies, past inflation, controls and the constant were included after differencing; regional dummies model region specific trends because regions are expected to grow at different rates. The models were White-corrected and sample size weighted, to account for the relative importance of each region (and for heteroskedasticity arising from aggregation).

Although estimates using the real minimum wage have been criticized (Sections 2.3.1 and 3.2), they are reported for completeness and for comparability with the existing literature. The first column of Table 2 shows robust and significant estimates, more robust for lower percentiles. An increase in the minimum wage affects the $10^{\text {th }}$ percentile four times more than the $90^{\text {th }}$ percentile of the wages distribution. A $10 \%$ increase in the minimum wage is associated with a wage increase of $6.29 \%$ (5.94\%) for those in the $10^{\text {th }}\left(20^{\text {th }}\right)$ percentile. This is in line with Manning's (1994) model that predicts a right shift of the whole distribution following a minimum wage increase. Fajnzylber (2001) used the same data source and sample period and also found significant wage effects throughout the distribution. Others found more limited spillovers (Neumark et al, 2003; Soares, 2002; Corseuil and Carneiro, 2001) (Section 3.3). Dickens et al. (1999) and Card and Krueger (1995) also document compression effect for the UK and US.

Larger estimates for lower percentiles are the counterpart of the compression effect in Graph 2. This can be also documented by regressing wage distribution percentile ratios on the same regressors as above. Table 2 shows that a $10 \%$ increase in the minimum wage decreases the $90^{\text {th }}$ to $10^{\text {th }}$ gap by $4.52 \%$, which

\footnotetext{
${ }^{5}$ There is some agreement in the literature that demand shifters should be held constant, but less agreement on whether supply shifters should be included as controls and, if so, which ones (Brown, 1999). Typically, employment equations have been interpreted as demand equations, even though many include supply side variables (Card and Krueger, 1995). Particularly debatable is the inclusion of a variable measuring enrolment rates in school (Card and Krueger, 1995; Neumark and Wascher, 1992 and 1996), which was not included here because of the unresolved debate (Williams, 1993; Baker et al., 1999).
} 
can be decomposed into decreasing the $50^{\text {th }}$ to $10^{\text {th }}$ gap by $3.28 \%$ and the $90^{\text {th }}$ to $50^{\text {th }}$ gap by $1.23 \%$. This suggests that compression is stronger in the bottom half of the distribution. The compression effect can be further documented by regressing a measure of dispersion (e.g., log standard deviation) on the same regressors; once more, the results are reassuring of the compression effect.

\subsection{Identification}

Within a month, the nominal minimum wage is a constant and therefore cannot explain variations in wages across regions. As discussed in Section 2.3.1, the variation in the real minimum wage cannot be regarded as genuine; the effect of the inverse of the deflator on wages is what is ultimately estimated (Welch and Cunningham, 1978; Freeman, 1982). Lacking genuine regional variation, the minimum wage coefficient is not robust to how the effect of other macro variables on wages is modelled. Identification requires regional variation of the minimum wage variable if no restriction on time modelling (e.g. through trends) is imposed.

Once regional variation is ensured, for example by using "degree of impact measures" (Section 2.3), year and regional dummies model time and regional fixed effects in the typical annual data model in the literature (Brown, 1999). The monthly analogue of this is the interaction of (12) seasonal-month and (16) year dummies. The implicit assumption is that the variation in the "degree of impact measures" is independent of the variation in the time dummies. However, because the minimum wage in the sample period is systematically increased on a particular month (May in 13/16 years), the variation on the "degree of impact measures" is also systematic. As a result, the (interaction of May and year) time dummies eliminate the variation that identifies the minimum wage coefficient because each dummy captures all that affects wages in May of each year - including minimum wage increases (Burkhauser et al., 2000) and the associated variation in the "degree of impact measures".

To prevent this, only the interaction of (11) seasonal-month and (16) year dummies, excluding the May interaction but including a seasonal-month May dummy, are included to model time fixed effects. The "degree of impact measures" then explain the variation in wages due to minimum wage variation over and above the variation explained by macro shocks both in each time period and seasonally in May. ${ }^{6}$

\footnotetext{
${ }^{6}$ To test whether the restricted model is a good approximation of the unrestricted model, a Wald test was implemented. The null could not be rejected up to the $40^{\text {th }}$ percentile when using the real minimum wage; this result was not robust when using “degree of impact measures". A more flexible version of the restricted model included dummies for May of 1986,1989 and 1990 to separate macro shocks from the Cruzado, Verao and Collor Plans (implemented in February of 1986, January of 1989 and March of 1990) possibly extending up to May. The results did not change qualitatively. Although the tests indicate that the restricted model does not capture all the relevant variation captured by the fully saturated model, the later is not an option because there is nothing but noise left to identify the minimum wage effect.
} 


\subsection{Model Re-specification}

As discussed in Section 3.2, the real minimum wage does not ensure full identification of the wage effect in Equation (1) and is replaced by the preferred "degree of impact measure" "fraction at" (Section 2.3.1). Column 2 of Table 2 shows estimates more robust and larger at lower percentiles. At higher percentiles, they are insignificant, suggesting limited spillover effects. These estimates were calibrated to represent the effect of a $10 \%$ increase in the minimum wage (Section 3.5). A $10 \%$ increase in the nominal minimum wage (increases "fraction at" by 0.3 percentage points and) increases the wages of those in the $10^{\text {th }}\left(20^{\text {th }}\right)$ percentile by $0.70 \%(0.30 \%)$. Table 2 also shows percentile ratios and standard deviation regressions, which confirm the compression effect.

Spillovers are more extensive when using the real minimum wage in Section 3.1 (up to the $90^{\text {th }}$ percentile) than when using "fraction at" (up to the $20^{\text {th }}$ percentile). Spillovers for Brazil are expected to be extensive because of the role the minimum wage played as wage coordinator and anti-inflation policy (Section 2.1). More generally, the compression effect is strong and spillovers are extensive for various countries in Latin America (Maloney and Mendez, 2003). However, the spillovers reported in Section 3.1 might result from artificial correlation between the real minimum wage and real wages, driven by the common (deflator) denominator. Additionally, those results are not fully identified (Section 3.2).

\subsection{Robustness Checks}

Although the "fraction at" estimates in Section 3.3 are more reliable than the real minimum wage estimates in Section 3.1, they need to be proved robust to further identification strategies. To carry out robustness checks, other "degree of impact measures" are used as minimum wage variables in place of the real minimum wage in Equation (1), namely "fraction affected" and "fraction below" (Section 2.3).

Columns 3 and 4 of Table 2 show estimates more robust and larger at lower percentiles. At higher percentiles they are insignificant, suggesting limited spillover effects, in line with the results for "fraction at" in Section 3.3. The estimates show a very similar pattern whatever minimum wage variable is used.

After calibration (Section 3.5), a 10\% increase in the nominal minimum wage (increases "fraction affected" by 3.7 percentage points and) increases the wages of those in the $10^{\text {th }}\left(20^{\text {th }}\right)$ percentile by $3.85 \%$ (4.51\%). These are larger than the "fraction at" estimates in Section 3.3, because "fraction affected" embraces a larger proportion of workers and therefore measures higher extra wages costs (spillovers just above the minimum wage). Card and Krueger (1995, p. 146) found estimates ranging from 0.18 to 0.30 when regressing the mean of log wages on "fraction affected", here comparable with 0.575 . This estimate is expected to be larger for Brazil because the minimum wage is more binding and increases are larger. 
Similarly, after calibration, a 10\% increase in the nominal minimum wage (increases "fraction below" by 1.4 percentage points and) increases the wages of those in the $10^{\text {th }}\left(20^{\text {th }}\right)$ percentile by $0.89 \%$ $(1.20 \%)$. These are larger than the "fraction at" estimates in Section 3.3, once again because "fraction below" embraces a larger proportion of workers and therefore measures higher extra wages costs (spillovers below the minimum wage). Neumark et al. (2003) found $0.45(-1.28)$ estimates for the $10^{\text {th }}$ $\left(20^{\text {th }}\right)$ percentile of the formal sector wage distribution in Brazil under low inflation (1996-2001) using "fraction below", here comparable with $0.636(0.345)$.

Table 2 presents the interval, the average and the standard deviation of the "degree of impact measures" estimates. A $10 \%$ increase in the nominal minimum wage increases the wages of those in the $10^{\text {th }}\left(20^{\text {th }}\right)$ percentile by $1.82 \%(2.00 \%)$ on average across variables. Table 2 also shows percentile ratios and standard deviation regressions estimates that confirm the compression effect. This effect was robust to various alternative minimum wage variables and specifications. This evidence is in line with theory and previous empirical evidence for Brazil and for other developed and developing countries (Brown, 1999; Card and Krueger, 1995; Maloney and Mendez, 2003; Neumark et al, 2003; Soares, 2002).

\subsection{Interpretation of estimates}

The implicit assumption when using "relative minimum wage measures" is that minimum wage increases do not affect overall price level, average or median wages substantially (Section 2.3.1). If the variation in the ratio comes from the variation in the nominal minimum wage, a $10 \%$ increase in the ratio is taken to represent a $10 \%$ increase in the nominal minimum wage and the "relative minimum wage measures" estimates are interpreted as the effect of the minimum wage on wages or employment.

Even assuming no spillovers and no inflationary effect, the "degree of impact measures" estimates cannot be interpreted as the effect of the minimum wage on wages or employment. Their estimates need to be calibrated to represent the effect of a $10 \%$ increase in the nominal minimum wage. That is because when the nominal minimum wage is increased, not all "degree of impact measures" are increased by the same proportion. For example, a 10\% increase in the nominal minimum wage increases "fraction at" by 0.3 , "fraction affected" by 3.7 and "fraction below" by 1.4 percentage points.

The 0.3 calibrating factor is the coefficient of the nominal minimum wage on a regression of difference of "fraction at" on the difference of log nominal minimum wage and the other regressors in Equation (1). ${ }^{7}$ However, because the nominal minimum wage does not vary across regions (Section 3.2), $\log$ "Kaitz index" and log "Kaitz index 50" were also used. The estimates were remarkably robust.

\footnotetext{
7 A deterministic model gives the intuition. Let $y=a_{1}+b_{1} x, y=a_{2}+b_{2} z$, and $z=a_{3}+b_{3} x ;$ then $b_{1}=b_{2} b_{3}$, $\forall b_{1}, b_{2}, b_{3} \neq 0$. In non-deterministic models, the more precise the estimates, the better $b_{1}$ approximates $b_{2} b_{3}$.
} 
Ideally, a structural model relating wages to "fraction at", and "fraction at" to the nominal minimum wage should be specified. However, to concentrate on the main issues of interest here, the above empirical models for "fraction at" were used. Card and Krueger (1995, p. 142) interpret their "fraction affected" estimates in a similar manner. The 3.7 and 1.4 calibrating factors were obtained in a similar manner.

\section{Employment Effects}

\subsection{Model Specification}

Having established the compression effect on the wages distribution, the policy debate hinges on the minimum wage employment effect. Consider the following empirical model, grounded on the standard neoclassical theoretical model, where employment is a function of the minimum wage:

$\log$ employment $_{r t}=\alpha^{e}+\beta^{e} \log r M W_{r t}+\gamma^{e} \inf$ lation $_{r t-1}+\lambda^{e}$ controls $_{r t}+\sum_{l=1}^{24} \rho_{l}^{e} \log$ employment $_{r t-1}+f_{r}^{e}+f_{t}^{e}+u_{r t}^{e}$

where employment $t_{r t}$ is employment (Section 4.2), and the other regressors are as in Section 3.1. Dynamics were allowed because the inability to adjust other inputs instantaneously to a minimum wage increase creates lagged responses in employment (Brown et al., 1982; Hamermesh, 1995). ${ }^{8}$

The model was estimated in levels and in first-differences. Dummies, past inflation, controls and the constant were included after differencing; the regional dummies model region specific trends (Section 3.1). The models were White-corrected and sample size weighted. By modeling regional and time fixed effects, including controls and dynamics, and differencing the data, the errors are no longer expected to be serially correlated over time. ${ }^{9}$

\subsection{Total Employment Effect Decomposition into Hours Effect and Jobs Effect}

The most common dependent variable in empirical minimum wage employment models is the ratio of employment to population (Brown et al., 1982). This variable measures the adjustment in the number of jobs following a minimum wage increase. However, not only the number of jobs, but also the number of hours worked is adjusted following an increase (Michl, 2000; Zavodny, 2000; Card and Krueger, 2000; Neumark and Wascher, 2000). As a result, the total effect of a minimum wage increase on employment can be decomposed into hours effect and jobs effect.

\footnotetext{
${ }^{8}$ Employment is reported AR(2) using annual data (Layard et al., 1991); the analogue here is 24 lags. The results were robust to 12 lags, but that prematurely censored the adjustment process because lags beyond 12 were significant.

${ }^{9}$ The results were robust to SUR estimation. GMM a la Arellano and Bond (1991) is not an option because T>N.
} 
Let average hours worked in the labour force $(\bar{T})$ be equal to the product of average hours worked for those working $(\bar{H})$ and the employment rate $(E)$. Then, $\bar{T}=\bar{H} E$ is $\frac{\sum_{i=1}^{N} \text { hour }_{i}}{N}=\frac{\sum_{i \in e}^{N} h^{N} N_{e}}{N_{e}} \frac{N_{e}}{N}$, where $N_{e}$ and $N$ are sample sizes of the employed and labour force and hour is hours worked.

This decomposition suggests not only the ratio of employment to population as a dependent variable, but also the total average hours worked and the average hours worked for those working. Thus, employment $_{r t}$ in Equation (2) is taken in turn to mean $\bar{T}, \bar{H}$, and $E$. Assuming the usual $\log \log$ form (Brown, 1999) and using the same set of regressors in each one of the three resulting equations, ${ }^{10}$ the estimate of the real minimum wage in the $\bar{T}$ equation equals the sum of the estimates of the real minimum wage in the $\bar{H}$ and $E$ equations, i.e. $\beta_{T}^{e}=\beta_{H}^{e}+\beta_{E}^{e}$. Zavodny (2000), Machin et al. (2003) and Neumark et al. (2003) estimate hours and jobs effects, but do not formalize it as a decomposition.

As discussed in Section 2.2, the raw correlations of both $\bar{H}$ and $E$ against $r M W$ offer little support for a negative employment effect. Nonetheless, such raw correlations need to be proved robust when the effect of other variables (demand and supply shocks) on employment is controlled for. Although estimates using the real minimum wage have been criticized (Sections 2.3.1 and 3.2), they are reported for completeness and for comparability with the existing literature. Panel I of Table 3 shows total effect, hours effect and jobs effect estimates, positive but mostly insignificant. A $10 \%$ increase in the minimum wage is associated with a $0.21 \%(0.15 \%)$ increase in total employment in the model in levels (differences), decomposed into $0.17 \%(0.15 \%)$ increase in the number of hours worked and $0.04 \%(0 \%)$ increase in the number of jobs. After two years of adjustments, total employment increases (decreases) by $0.11 \%(0.11 \%)$. This effect is smaller than the $-1 \%$ effect in the literature (Sections 1 and 4.5 ). Neumark et al. (2003) estimates small negative but not always significant hours (-0.9\%) and jobs (-0.6\%) effects for Brazil using formal sector data in low inflation period, when more adverse employment effects are expected (Section 4.5). The specification in differences is preferred because it is more reliable both conceptually (Section 3.1) and statistically (less serial correlation); it is also comparable with the typical specification in the literature.

\subsection{Identification and Model Re-specification}

As discussed in Section 3.2, the real minimum wage does not ensure full identification of the employment effect in Equation (2) and is replaced by the preferred "degree of impact measure" "fraction

\footnotetext{
${ }^{10}$ Because of dynamics, the set of regressors is not the same in all three equations and the OLS additivity property does not hold exact. To preserve the decomposition, lagged $\bar{T}$, which embodies the variation of $\bar{H}$ and $E$, was used in all three equations without affecting the robustness of the estimates.
} 
at" (Section 2.3.1). Panel II of Table 3 shows that the total and hours effect estimates are significant and positive; and that the jobs effect estimates are negative and insignificant. The total effect estimates are positive because they are dominated by the hours effect (Brown, 1999). After calibration (Section 3.5), a $10 \%$ increase in the nominal minimum wage (increases "fraction at" by 0.3 percentage points and) increases total employment by $0.059 \%$, decomposed into $0.060 \%$ increase in hours worked and $0.001 \%$ decrease in jobs (model in differences). After two years, total employment decreases by $0.043 \%$. These results are larger than those using the real minimum wage in Section 4.2, and as discussed in Section 3.2, also more reliable.

\subsection{Robustness Checks}

As in Section 3.4, the "fraction at" estimates in Section 4.3 need to be proved robust to further identification strategies. To carry out robustness checks, other minimum wage variables are used in place of the real minimum wage in Equation (2), namely: "fraction affected", "fraction below", log "Kaitz index" and log "Kaitz index 50". Although estimates using the "Kaitz index" variables have been criticized (Sections 2.3.1 and 3.2), they are reported for completeness and for comparability with the existing literature.

Panel III of Table 3 shows estimates for "fraction affected". 11 They are positive, but the jobs effect estimate is insignificant. After calibration (Section 3.5), a 10\% increase in the nominal minimum wage (increases "fraction affected" by 3.7 percentage points and) increases total employment by $0.012 \%$, decomposed into $0.012 \%$ increase in hours worked and $0 \%$ decrease in jobs. After two years, total employment decreases by $0.009 \%$. These are four times smaller than the "fraction at" estimates in Section 4.3, even though wage effects were larger (Section 3.4). Card and Krueger (1995, p. 144) found estimates ranging from 0.03 to 0.36 when regressing the change of employment-population ratio on "fraction affected", here comparable to the jobs estimate (0.001).

Panel IV of Table 3 shows significant estimates for "fraction below". The total and hours effect estimates are positive; the jobs effect estimates is negative (positive) in the model in levels (differences). After calibration (Section 3.5), a 10\% increase in the nominal minimum wage (increases "fraction below" by 1.4 percentage points and) increases total employment by $0.134 \%$, decomposed into $0.127 \%$ increase in hours worked and $0.007 \%$ decrease in jobs (model in differences). After two years, total employment decreases by $0.093 \%$. These estimates are larger than the "fraction at" and "fraction affected" estimates above because "fraction below" embraces a larger proportion of workers and thus measures extra wage (spillovers are larger at the bottom of the distribution) and employment costs.

\footnotetext{
${ }^{11}$ Because fraction is already in differences (it is defined over two time periods) the models in levels cannot be defined.
} 
Panels V and VI show significant estimates for "Kaitz index" and "Kaitz index 50". The total and hours effect estimates are positive; the jobs effect estimates is negative (positive) in the model in levels (differences). A 10\% increase in the "Kaitz index" or "Kaitz index 50" increases (decreases) total employment by no more than $0.48 \%(0.32 \%)$ in the short (long) run. These are larger than the "degree of impact measures" estimates above because they account for spillover effects up to the average or median.

In sum, the "degree of impact measures" estimates are the smallest, followed by the real minimum wage estimates and then by the "Kaitz index" variables estimates. The "Kaitz index" variables estimates in absolute terms are roughly four (three) times larger than the largest "degree of impact measures" estimates in the short (long) run. Table 3 presents the interval of the "degree of impact measures" estimates. A $10 \%$ increase in the nominal minimum wage increases (decreases) total employment by no more than $0.13 \%(0.09 \%)$ in the short (long) run. In the preferred "fraction at" specification in differences, these are $0.059 \%(0.043 \%)$. The total employment effect is dominated by the hours effect (Brown, 1999), with the jobs effect either not statistically or not mathematically (much) different from zero. The sign of the total employment and hours effects were remarkably robust; the sign of the jobs effect, when significant, was sensitive to the data filter. The sign of the long run effects was clearly sensitive to the data filter.

The employment effect here estimated was robust to various alternative minimum wage variables. This effect is smaller than the $-1 \%$ effect in the literature (Sections 1 and 4.5 ). Regarding the above as demand equations, the results are consistent with an inelastic demand curve (Freeman, 1995); minimum wage increases translate into small employment and large wage effects. In other words, the minimum wage increases the wages of low paid workers and does not destroy many jobs in Brazil. Barros et al. (2001) estimated an inelastic labour demand curve for the industry sector in Brazil.

\subsubsection{Comparing Non Comparable Estimates}

Different estimate magnitudes and significance, and perhaps even different signs, might stem from the use of different minimum wage variables, which are not always directly comparable. This could happen because of two main reasons.

First, the associated estimates need to be calibrated to represent the effect of a $10 \%$ increase in the minimum wage on employment (Section 3.5). Comparing the estimates before calibration is misleading. A quick inspection of Table 3 shows that the "Kaitz index" variables estimates are smaller than the "degree of impact measures" estimates before, and larger after calibration.

Second, different variables measure the effect of the minimum wage on different workers. The above estimates suggest that the sign of the estimates is not sensitive to the minimum wage variable, although the magnitude and significance are. On the one hand, the correlation between each of the 
minimum wage variables and the real minimum wage is positive (Section 2.3) and thus the estimates are expected to carry the same sign. (The sign of the estimates was affected by the data filter (Section 4.4)). On the other hand, the more spillovers the variable measures, the larger the estimates are expected to be: (a) the "Kaitz index" variables show the largest estimates, as they account for spillovers up to the average or median, followed by the real minimum wage estimates, which account for overall wage-price spillovers; (b) the "fraction below" shows the next largest estimates, as they account for spillovers below the minimum wage; (c) the "fraction at" estimates are smaller than the last ones, as they measure no spillovers. The "fraction affected" estimates should be larger than the "fraction at" estimates, as the first measures spillovers just above the minimum wage. However, "fraction affected" is not as reliable minimum wage variable and its estimates do not fully identify the minimum wage (and spillover) effect (Section 2.3.1).

Thus, even after calibration, the above estimates are not directly comparable. Not only conceptually they measure the effect of minimum wage increases on different workers, but also statistically the real minimum wage, the "Kaitz index" variables and the "fraction affected" are not as reliable (Sections 2.3 and 3.2). If the conceptual question is then narrowed to the effect of the minimum wage clear of spillovers, "fraction below" is left out and "fraction at" produces the preferred estimates.

\subsection{Why are Employment Effects Small?}

Even though the main goal here is to compare estimates across minimum wage variables, since the overall magnitude of the estimates is substantially smaller than that found in the international literature (Sections 1 and 4.4), tentative explanations are offered.

The most obvious explanation is that the estimates here are for the entire labour force and therefore potential employment effects for low wage groups have been diluted. Estimates for teenagers or low educated workers, as it is common in the US literature (Brown, 1999), should be larger. Lemos (2004a) estimates a larger long run total employment effect for teenagers $(-0.083 \%)$ and low educated $(-0.069 \%)$ in Brazil (to be compared with the $-0.043 \%$ long run total employment effect in the preferred specification here). These are, however, still smaller than the $-1 \%$ effect in the literature.

Another obvious explanation, which has received little attention in the literature, is the standard theory prediction that an industry wide cost shock will be passed on to prices. Firms will not incur in employment adjustment costs if they are able to pass through to prices the higher costs associated to a minimum wage shock. Lemos (2003a) estimates significant price partial pass-through effect of the minimum wage in Brazil. Small employment effects are sensible if coupled with price effects. Furthermore, the higher the inflation, the lesser the resistance firms encounter to upward price adjustments. Lemos (2003b) estimates larger adverse long run total employment effects in low (-0.125\%) 
than in high (-0.029\%) inflation periods in Brazil. Neumark et al. (2003) and Fjnzylber (2001) estimate negative jobs effects for the formal sector in Brazil; the first finds a larger effect $(-0.6 \%)$ using late $90 \mathrm{~s}$ data, a low inflation period, and the second finds a smaller effect (-0.01\%) using $80 \mathrm{~s}$ and $90 \mathrm{~s}$ data, in the main was a high inflation period.

A final obvious explanation is that there is little reason to believe that employment effects would be too adverse in a country where non-compliance is large and the public sector has an inelastic labour demand, such as in Brazil. With no social security and worsening macroeconomic conditions (Section 2.2), people cannot afford being out of employment and accept underpaid work in the informal sector. Various authors estimated small negative employment effects in both sectors in Brazil (Lemos, 2004b; Foguel, 1997; Gonzaga et al., 1999; Fajnzylber, 2001). Lemos (2004b) estimates small long run total employment effects in both the formal $(-0.103 \%)$ and informal $(-0.194 \%)$ sectors and in the private ($0.067 \%)$ and public $(0.040 \%)$ sectors in Brazil.

\section{Conclusion}

Using under-explored Brazilian household data for the 80s and 90s this paper estimates and critically compares the effects of the minimum wage on both wages and employment using five minimum wage variables common in the literature: real minimum wage, "Kaitz index", "fraction affected", "fraction at" and "fraction below" the minimum wage. The main goal is to assess whether sensitiveness of the estimates to different minimum wage variables offer an explanation to the controversial recent debate in the literature over the magnitude and direction of the employment effect.

The above estimates suggest that the sign of the estimates is not sensitive to the minimum wage variable, although the magnitude and significance are. On the one hand, the correlation among the minimum wage variables is positive and thus the estimates carried the same sign. On the other hand, the more spillovers the minimum wage variable measured, the larger the employment effect was.

Even after calibrating the estimates of different minimum wage variables to represent the effect of a $10 \%$ increase in the minimum wage on employment, the estimates were not directly comparable. Not only conceptually they measure the effect of minimum wage increases on different workers, but also statistically the real minimum wage, the "Kaitz index" and the "fraction affected" are not reliable. If the conceptual question is then narrowed to the effect of the minimum wage clear of spillovers, "fraction below" is left out and "fraction at" produces the preferred estimates.

Overall, the estimates were robust across variables and indicate that an increase in the minimum wage compresses the wages distribution with small adverse effects on employment. This suggests that the minimum wage increases the wages of low paid workers and does not destroy many jobs in Brazil. Using the "fraction at" preferred estimates, an increase of $10 \%$ in the minimum wage was found to 
decrease the number of jobs by no more than $0.001 \%$ but to increase total employment (via increase in the number of hours worked) by $0.059 \%$ in the short run. After two years of adjustment, total employment was decreased by no more than $0.043 \%$. These employment effects are smaller than the $-1 \%$ effect in the international literature because of specificities of the Brazilian Economy.

\section{References}

AKERLOF, G. A. (1982): "Labor Contracts as Partial Gift Exchange," Quarterly Journal of Economics, 97, 543569.

— (1984): "Gift Exchange and Efficiency-Wage Theory: Four Views," American Economic Review, 74, 79-83.

ARELlANO, M., and S. BOND (1991): "Some Tests of Specification for Panel Data: Monte Carlo Evidence and an Application to Employment Equations," Review of Economic Studies, 58, 277-297.

BACHA, E. (1979): "Crescimento Economico, Salarios Urbanos E Rurais: O Caso Do Brasil," Pesquisa e Planejamento Economico, 9, 585-627.

BAKER, M., D. BENJAMIN, and S. STANGER (1999): "The Highs and Lows of the Minimum Wage Effect: A Time-Series Cross-Section Study of the Canadian Law," Journal of Labor Economics, 17, 318-350.

BARROS, R. P., C. H. CORSEUIL, and G. GONZAGA (2001): "A Evolucao Da Demanda Por Trabalho Na Industria Brasileira: Evidencias De Dados Por Estabelecimento--1985/97," Pesquisa e Planejamento Economico, $31,187-211$.

BROWN, C. (1999): "Minimum Wages, Employment, and the Distribution of Income," in Handbook of Labor Economics, ed. by O. Ashenfelter, and D. Card. Amsterdam; New York and Oxford: Elsevier Science, NorthHolland, 2101-2163.

BROWN, C., C. GILROY, and A. KOHEN (1982): "The Effect of the Minimum Wage on Employment and Unemployment," Journal of Economic Literature, 20, 487-528.

BURKHAUSER, R. V., K. A. COUCH, and D. C. WITTENBURG (2000): "A Reassessment of the New Economics of the Minimum Wage Literature with Monthly Data from the Current Population Survey," Journal of Labor Economics, 18, 653-680.

CAMARGO, J. M. (1984): "Minimum Wage in Brazil Theory, Policy and Empirical Evidence," PUC Working Paper, 67.

CARD, D. (1992): "Do Minimum Wages Reduce Employment? A Case Study of California, 1987-89," Industrial and Labor Relations Review, 46, 38-54.

CARD, D. E., and A. B. KRUEGER (1995): Myth and Measurement: The New Economics of the Minimum Wage. Princeton: Princeton University Press.

- (2000): "Minimum Wages and Employment: A Case Study of the Fast-Food Industry in New Jersey and Pennsylvania: Reply," American Economic Review, 90, 1397-1420.

CARNEIRO, F., and J. FARIA (1998): "O Salario Minimo E Os Outros Salarios No Brasil," Anais do XXVI Encontro Nacional de Economia, 1169-1180.

CARNEIRO, F. G. (2002): "Uma Resenha Empirica Sobre Os Efeitos Do Salario Minimo No Mercado De 
Trabalho Brasileiro," Unpublished Paper.

CASTILLO FREEMAN, A. J., and R. B. FREEMAN (1992): "When the Minimum Wage Really Bites: The Effect of the U.S.-Level Minimum on Puerto Rico," in Immigration and the Work Force: Economic Consequences for the United States and Source Areas, ed. by G. J. Borjas, and R. B. Freeman. Chicago and London: University of Chicago Press, 177-211.

CORSEUIL, C. H., and F. G. CARNEIRO (2001): "Os Impactos Do Salario Minimo Sobre Emprego E Salarios No Brasil: Evidencias a Partir De Dados Longitudinais E Series Temporais," Unpublished Paper.

CORSEUIL, C. H., and L. SERVO (2002): "Salario Minimo E Bem Estar Social No Brasil: Uma Resenha Da Literatura," Unpublished Paper.

CURRIE, J., and B. C. FALLICK (1996): "The Minimum Wage and the Employment of Youth: Evidence from the Nlsy," Journal of Human Resources, 31, 404-428.

DEERE, D., K. M. MURPHY, and F. WELCH (1995): "Employment and the 1990-1991 Minimum-Wage Hike," American Economic Review, 85, 232-237.

— (1996): "Examining the Evidence on Minimum Wages and Employment," in The Effects of the Minimum Wage on Employment, ed. by M. Kosters. Washington: AEI Press, 26-54.

DICKENS, R., S. MACHIN, and A. MANNING (1999): "The Effects of Minimum Wages on Employment: Theory and Evidence from Britain," Journal of Labor Economics, 17, 1-22.

DOLADO, J., and ET AL. (1996): "The Economic Impact of Minimum Wages in Europe," Economic Policy: A European Forum, 23, 317-357.

FAJNZYLBER, P. (2001): "Minimum Wage Effects Throughout the Wage Distribution: Evidence from Brazil's Formal and Informal Sectors," Anais do XXIX Encontro Nacional de Economia.

FERNANDES, R., and N. A. MENEZES-FILHO (2000): "A Evolucao Da Desigualdade No Brasil Metropolitano Entre 1983 E 1997," Estudos Economicos, 30, 549-569.

FREEMAN, R. (1982): "Economic Determinants of Geographic and Individual Variation in the Labor Market Position of Young Persons," in The Youth Labor Market Problems: Its Nature, Causes and Consequences, ed. by R. Freeman, and D. Wise, 115-148.

— (1994): "Minimum Wages--Again!," International Journal of Manpower, 15, 8-25.

— (1995): "What Will a 10\%...50\%...100\% Increase in the Minimum Wage Do?," Industrial and Labor Relations Review, 48, 830-838.

— (1996): "The Minimum Wage as a Redistributive Tool," Economic Journal, 106, 639-649.

FOGUEL, M. N., L. RAMOS, and F. CARNEIRO (2001): "The Impacts of the Minimum Wage on the Labor Market, Poverty and Fiscal Budget in Brazil," Unpublished Paper.

GRAMLICH, E. M. (1976): "Impact of Minimum Wages on Other Wages, Employment, and Family Incomes," Brookings Papers on Economic Activity, 2, 409-451.

GROSSMAN, J. B. (1983): "The Impact of the Minimum Wage on Other Wages," Journal of Human Resources, 18, 359-378.

HAMERMESH, D. (1995): "What a Wonderful World This Would Be," Industrial and Labor Relations Review, 48, 835-838. 
— (2002): "International Labor Economics," Journal of Labor Economics, 20, 709-732.

KAITZ, H. (1970): "Experience of the Past: The National Minimum, Youth Unemployment and Minimum Wages," US Bureau of Labor Statistics Bulletin, 1657, 30-54.

LAYARD, R., S. NICKELL, and R. JACKMAN (1991): Unemployment. UK: Oxford University Press.

LEMOS, S. (2003a): “The Effects of the Minimum Wage on Prices in Brazil”, UCL Working Paper.

—. (2003b): "The Effects of the Minimum Wage on Wages, Employment and Prices in Brazil in Periods of High and Low Inflation", Unpublished Paper.

- (2004a): "Minimum Wage Effects across Population Groups in Brazil", Unpublished Paper.

— (2004b): "The Effects of the Minimum Wage Across Sectors in Brazil”, Unpublished Paper.

MACEDO, R., and M. GARCIA (1978): "Observacoes Sobre a Politica Brasileira De Salario Minimo," IPE/FEA/USP Trabalho para Discussao, 27.

— (1980): "Salario Minimo E Taxa De Salarios No Brasil," Pesquisa e Planejamento Economico, 10, 1013-1044.

MACHIN, S., and A. MANNING (1994): "The Effects of Minimum Wages on Wage Dispersion and Employment:

Evidence from the U.K. Wages Councils," Industrial and Labor Relations Review, 47, 319-329.

MACHIN, S., A. MANNING, and L. RAHMAN (2003): "Where the Minimum Wage Bites Hard: Introduction of Minimum Wages to a Low Wage Sector," Journal of The European Economic Association, Inaugural Issue, 154-180.

MALONEY, W., and J. MENDEZ (2003): "Minimum Wages in Latin America," Unpublished Paper.

MANNING, A. (1994): "Labour Markets with Company Wage Policies," London School of Economics Centre for Economic Performance Discussion Paper., 214.

MCINTYRE, F. (2002): "How Does the Minimum Wage Affect Market Informality in Brazil," Unpublished Paper.

MEYER, R. H., and D. A. WISE (1983): "Discontinuous Distributions and Missing Persons: The Minimum Wage and Unemployed Youth," Econometrica, 51, 1677-1698.

MICHL, T. R. (2000): "Can Rescheduling Explain the New Jersey Minimum Wage Studies?," Eastern Economic Journal, 26, 265-276.

NERI, M. (1997): "A Efetividade Do Salario Minimo No Brasil: Pobreza, Efeito-Farol E Padroes Regionais," Unpublished Paper.

NEUMARK, D., W. CUNNINGHAM, and L. SIGA (2003): "The Distributional Effects of Minimum Wages in Brazil: 1996-2001," Unpublished Paper.

NEUMARK, D., and W. WASCHER (1992): "Employment Effects of Minimum and Subminimum Wages: Panel Data on State Minimum Wage Laws," Industrial and Labor Relations Review, 46, 55-81.

- (1994): "Employment Effects of Minimum and Subminimum Wages: Panel Data on State Minimum Wage Laws: Reply to Car, Katz, and Krueger," Industrial and Labor Relations Review, 47, 497-512.

- (1996): "The Effects of Minimum Wages on Teenage Employment and Enrollment: Evidence from Matched Cps Surveys," in Research in Labor Economics, ed. by S. W. Polachek. London: JAI Press, 25-63.

- (2000): "Minimum Wages and Employment: A Case Study of the Fast-Food Industry in New Jersey and Pennsylvania: Comment," American Economic Review, 90, 1362-1396. 
SELLEKAERTS, B. (1981): "Impact of Minimum Wage Legislation on Wage and Price Inflation," Report of the Minimum Wage Study Commission, 6, 1-17.

SOARES, S. S. D. (2002): "O Impacto Distributivo Do Salario Minimo: A Distribuicao Individual Dos Rendimentos Do Trabalho," Unpublished Paper.

SOUZA, P., and P. BALTAR (1979): "Salario Minimo E Taxa De Salarios No Brasil," Pesquisa e Planejamento Economico, 9, 629-660.

— (1980): "Salario Minimo E Taxa De Salarios No Brasil - Replica," Pesquisa e Planejamento Economico, 10, 1045-1058.

THE ECONOMIST (2002a) “Talking victory”, October, $24^{\text {th }}$.

- (2002b) "Lula scents victory at last", September, $19^{\text {th. }}$

- (2003) "Fixing the finances", February, $20^{\text {th }}$.

WELCH, F. R., and J. CUNNINGHAM (1978): "Effects of Minimum Wages on the Level and Age Composition of Youth Employment," Review of Economics and Statistics, 60, 140-145.

WILLIAMS, N. (1993): "Regional Effects of the Minimum Wage on Teenage Employment," Applied Economics, $25,1517-1528$.

ZAVODNY, M. (2000): "The Effect of the Minimum Wage on Employment and Hours," Labour Economics, 7, 729-750. 


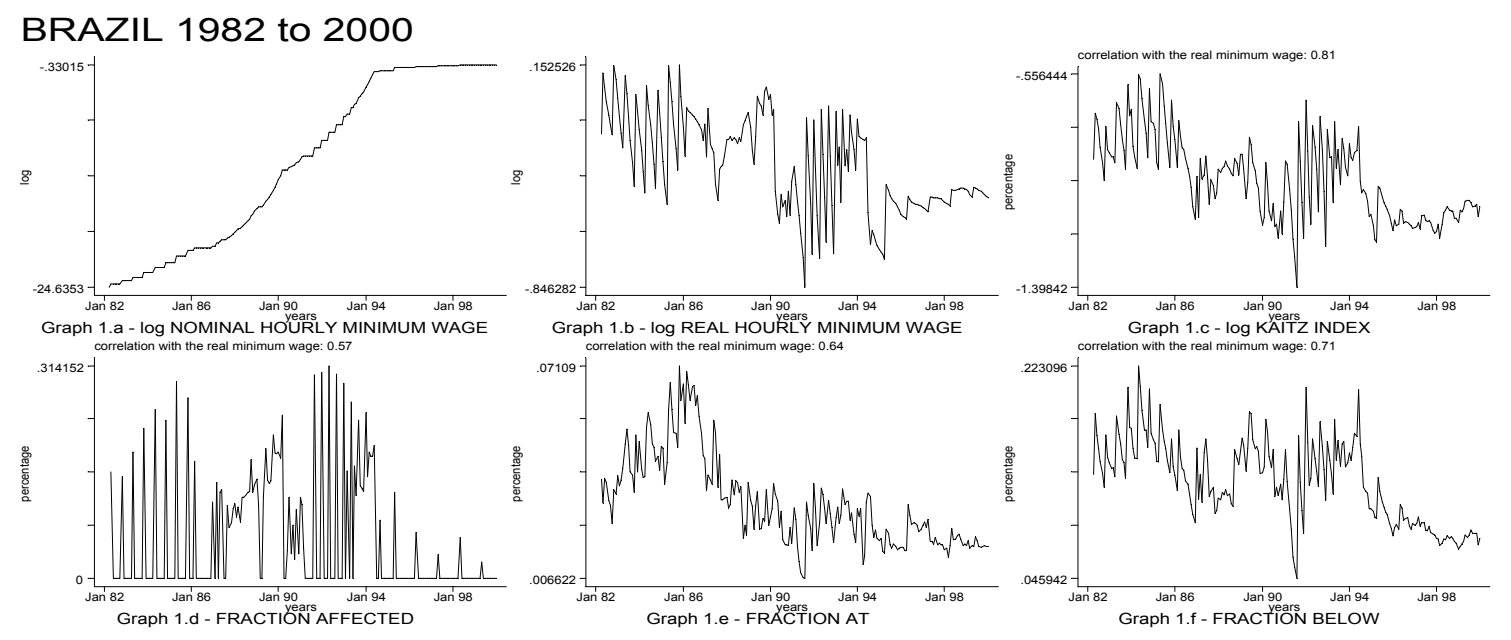

Graph 1 - MINIMUM WAGE VARIABLES

BRAZIL January to December 1992
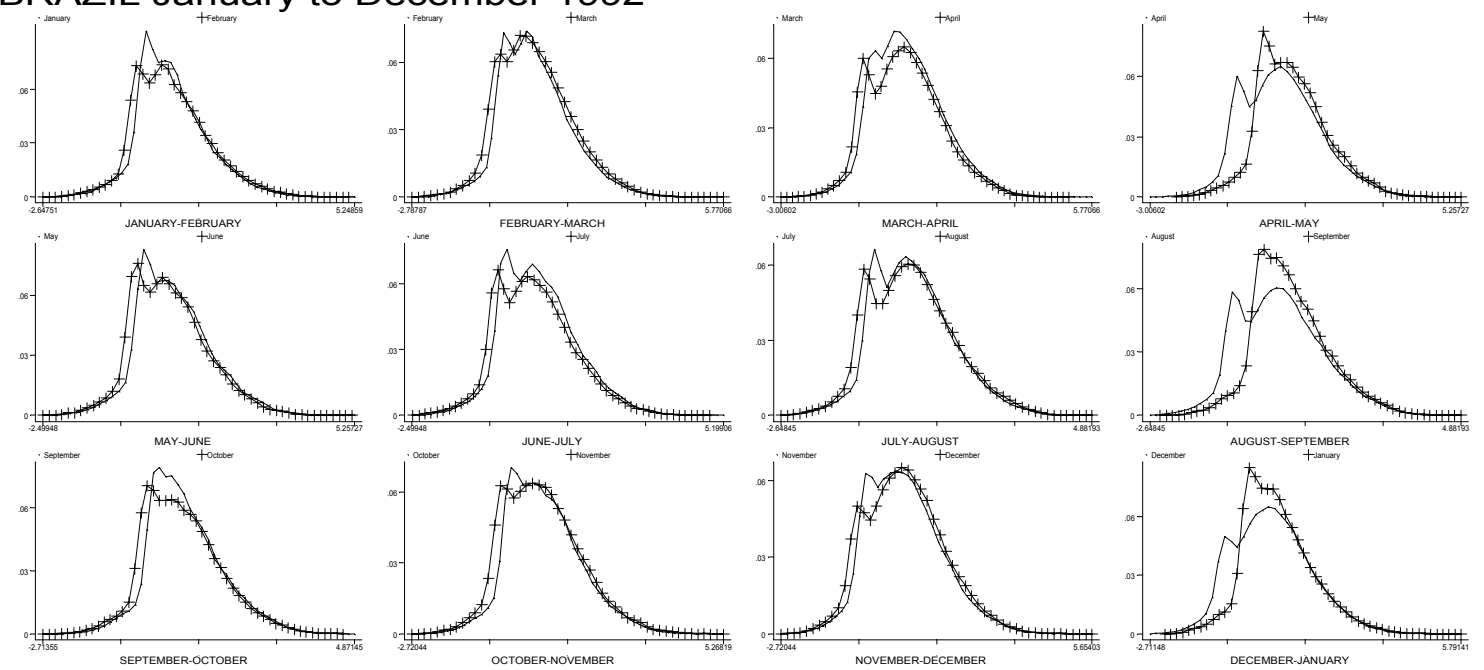

Graph 2 - WAGES DISTRIBUTIONS 
Table 1 - DESCRIPTIVE STATISTICS ACROSS REGIONS

\begin{tabular}{|c|c|c|c|c|c|c|}
\hline \multirow[t]{3}{*}{ VARIABLES } & \multicolumn{2}{|c|}{$\begin{array}{ll}\text { BR } & \text { (full sample) } \\
& \text { all } \\
\end{array}$} & PE & ooor region) & \multicolumn{2}{|c|}{ (rich region } \\
\hline & Dec-84 & Dec-92 & Dec-84 & Dec-92 & Dec-84 & Dec-92 \\
\hline & (1) & (2) & (3) & (4) & $(5)$ & (6) \\
\hline \multicolumn{7}{|c|}{ I - POPULATION VARIABLES - $\%$ of those in the population who are: } \\
\hline aged 0 to 14 years old & 16 & 17 & 21 & 19 & 14 & 16 \\
\hline aged 15 to 24 years old & 27 & 24 & 28 & 27 & 26 & 24 \\
\hline aged 25 to 64 years old & 51 & 51 & 44 & 46 & 54 & 53 \\
\hline aged over 65 years old & 6 & 7 & 7 & 7 & 5 & 7 \\
\hline women & 42 & 45 & 43 & 46 & 41 & 43 \\
\hline student & 24 & 26 & 32 & 30 & 18 & 23 \\
\hline enrolled & 31 & 32 & 39 & 37 & 27 & 31 \\
\hline literated & 91 & 93 & 81 & 86 & 93 & 95 \\
\hline basic education (4 years of schooling) & 35 & 42 & 39 & 45 & 32 & 40 \\
\hline elementary education (8 years of schooling) & 25 & 19 & 19 & 15 & 28 & 21 \\
\hline secondary education (11 years of schooling) & 11 & 14 & 11 & 13 & 9 & 13 \\
\hline graduates & 8 & 9 & 6 & 8 & 9 & 11 \\
\hline retired & 10 & 12 & 12 & 13 & 9 & 11 \\
\hline in urban areas & 96 & 94 & 89 & 89 & 97 & 96 \\
\hline \multicolumn{7}{|c|}{ II - LABOUR MARKET VARIABLES - \% of those workers who are working in: } \\
\hline metallurgic industry & 21 & 18 & 14 & 12 & 34 & 27 \\
\hline building construction & 8 & 8 & 7 & 6 & 6 & 7 \\
\hline commerce & 15 & 15 & 18 & 17 & 13 & 15 \\
\hline services & 47 & 50 & 44 & 50 & 43 & 47 \\
\hline public sector & 13 & 12 & 14 & 13 & 7 & 9 \\
\hline informal sector & 22 & 23 & 25 & 27 & 21 & 22 \\
\hline \multicolumn{7}{|l|}{ III - ECONOMIC VARIABLES } \\
\hline employment rate & $90.8 \%$ & $90.8 \%$ & $87.2 \%$ & $85.9 \%$ & $92.2 \%$ & $91.0 \%$ \\
\hline average hours worked by those employed & 38.9 & 39.0 & 42.1 & 39.9 & 38.4 & 39.7 \\
\hline average hours worked in the working population & 35.3 & 35.4 & 36.7 & 34.2 & 35.4 & 36.2 \\
\hline log hourly real minimum wage & -0.1 & -0.7 & -0.1 & -0.8 & 0.1 & -0.6 \\
\hline $\log 25$ th percentile hourly real wage distribution & 0.1 & -0.2 & -0.1 & -0.6 & 0.5 & 0.0 \\
\hline log 50th percentile hourly real wage distribution & 0.6 & 0.5 & 0.3 & 0.0 & 1.1 & 0.5 \\
\hline $\log 75$ th percentile hourly real wage distribution & 1.3 & 1.2 & 0.9 & 0.8 & 1.8 & 1.1 \\
\hline log average hourly real wage distribution & 0.7 & 0.6 & 0.4 & 0.2 & 1.2 & 2.2 \\
\hline log standard deviation hourly real wage distributior & 1.0 & 1.0 & 1.0 & 1.1 & 1.0 & 0.9 \\
\hline sample size & 111346 & 83532 & 15814 & 13010 & 23928 & 16369 \\
\hline
\end{tabular}

Table 2 - ESTIMATES OF THE COEFFICIENTS OF THE MINIMUM WAGE VARIABLES ON WAGES MODELS

\begin{tabular}{|c|c|c|c|c|c|c|c|c|c|c|c|c|}
\hline \multirow[t]{2}{*}{ percentiles } & \multicolumn{2}{|c|}{$\begin{array}{r}\text { MW } \\
\text { difference } \\
\end{array}$} & \multicolumn{2}{|c|}{$\begin{array}{r}\text { fraction } \\
\text { at }\end{array}$} & \multirow{2}{*}{$\begin{array}{r}\text { fraction } \\
\text { affected } \\
\text { coef } \\
(3) \\
\end{array}$} & \multicolumn{3}{|c|}{$\begin{array}{r}\text { fraction } \\
\text { below } \\
\end{array}$} & \multicolumn{4}{|c|}{$\begin{array}{l}\text { summary (over columns } 2 \text { to } 4 \text { ) } \\
\text { (calibrated to represent a } 10 \% \mathrm{MW} \text { increase) }\end{array}$} \\
\hline & $\begin{array}{r}\text { coef } \\
(1)\end{array}$ & $\mathrm{se}$ & $\begin{array}{r}\text { coef } \\
(2) \\
\end{array}$ & se & & se & $\begin{array}{r}\text { coef } \\
(4)\end{array}$ & se & $\begin{array}{r}\min \\
(5) \\
\end{array}$ & $\begin{array}{r}\max \\
(6)\end{array}$ & $\begin{array}{l}\text { av } \\
(7\end{array}$ & $\begin{array}{l}\text { sd } \\
(8)\end{array}$ \\
\hline 10th & 0.629 & 0.053 & 2.349 & 0.650 & 1.041 & 0.115 & 0.636 & 0.329 & 0.705 & 3.851 & 1.82 & 1.77 \\
\hline 20th & 0.594 & 0.064 & 1.012 & 0.534 & 1.218 & 0.099 & 0.856 & 0.299 & 0.304 & 4.506 & 2.00 & 2.21 \\
\hline 30th & 0.440 & 0.060 & -0.289 & 0.462 & 0.933 & 0.089 & 0.345 & 0.245 & -0.087 & 3.454 & 1.28 & 1.90 \\
\hline 40th & 0.358 & 0.039 & -0.348 & 0.361 & 0.684 & 0.069 & 0.088 & 0.200 & -0.105 & 2.531 & 0.85 & 1.46 \\
\hline 50th & 0.275 & 0.035 & -0.667 & 0.319 & 0.492 & 0.062 & -0.058 & 0.186 & -0.200 & 1.822 & 0.51 & 1.13 \\
\hline 90th & 0.159 & 0.036 & -0.488 & 0.379 & 0.197 & 0.068 & -0.518 & 0.166 & -0.726 & 0.730 & -0.05 & 0.73 \\
\hline mean & 0.327 & 0.031 & -0.049 & 0.316 & 0.575 & 0.060 & 0.029 & 0.171 & -0.015 & 2.128 & 0.72 & 1.22 \\
\hline 90th/10th & -0.452 & 0.054 & -3.041 & 0.629 & -0.832 & 0.104 & -1.186 & 0.274 & -3.078 & -0.912 & -1.88 & 1.10 \\
\hline 50th/10th & -0.328 & 0.048 & -3.084 & 0.521 & -0.527 & 0.093 & -0.687 & 0.226 & -1.950 & -0.925 & -1.28 & 0.58 \\
\hline 90th/50th & -0.123 & 0.028 & -0.043 & 0.330 & -0.305 & 0.049 & -0.498 & 0.133 & -1.128 & -0.013 & -0.61 & 0.56 \\
\hline st deviation & -0.143 & 0.015 & -0.650 & 0.166 & -0.279 & 0.025 & -0.276 & 0.081 & -1.034 & -0.195 & -0.54 & 0.44 \\
\hline \multicolumn{13}{|c|}{$\begin{array}{l}\text { 1) Columns } 1-4 \text { show estimates for respectively: real minimum wage, fraction at the minimum wage, fraction affected, and fraction below the minimum wage (see Section } 2.3 \text { ). } \\
\text { 2) Percentile regressions are shown for selected percentiles, followed by percentile ratio and standard deviation regressions. The dependent variable is the various percentiles, } \\
\text { ratios of percentiles and standard deviation of the wages distribution. }\end{array}$} \\
\hline \multicolumn{13}{|c|}{$\begin{array}{l}\text { 3) Time effects are modelled with interactions of year and seasonal-month dummies (the seasonal-month May dummy is not interacted, see Section } 3.2 \text { ). Population and } \\
\text { institutional factors are controlled for. } \\
\text { 4) Columns } 5-6 \text { show the interval that brackets the effect of a } 10 \% \text { increase in the minimum wage using the degree of impact estimates; columns } 7-8 \text { show the corresponding } \\
\text { average estimate and standard deviation. To calibrate the estimates in columns } 2-4 \text { to obtain the numbers in columns } 5-8 \text {, multiply the estimates of fraction at by } 0.3 \text {, of } \\
\text { fraction affected by } 3.7 \text { and of fraction below by } 1.4 \text { (see Section } 3.3 \text { ). }\end{array}$} \\
\hline
\end{tabular}



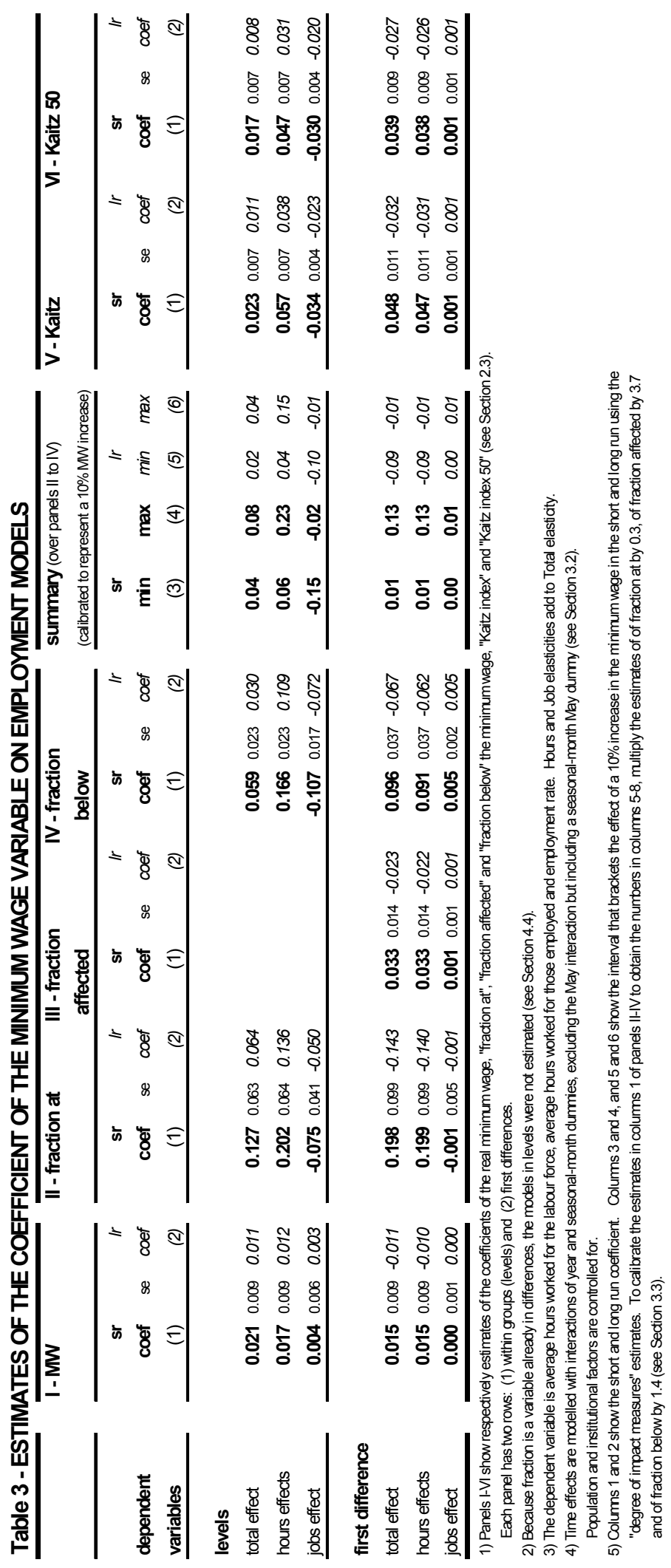